\title{
The impact of ISO 9000 and EFQM on the use of flexible work practices ${ }^{+}$
}

Alberto Bayo-Moriones*

Universidad Pública de Navarra

Departamento de Gestión de Empresas

\section{Javier Merino-Díaz-de-Cerio}

Universidad Pública de Navarra

Departamento de Gestión de Empresas

\section{Sergio Antonio Escamilla-de-León}

Universitat Autónoma de Barcelona

Departament d'Economia de l'Empresa

\section{Rejina Mary Selvam}

Universitat Autónoma de Barcelona

Departament d'Economia de l'Empresa

\begin{abstract}
The purpose of this paper is to analyse the differences between the two most frequently used quality management approaches implemented by firms, ISO 9000 and EFQM, in terms of their impact on the adoption of innovative work organization practices. In order to accomplish this objective, we have selected a sample of 665 establishments with at least 20 employees, from the manufacturing, building and service sectors. Results show that, as expected, EFQM involves an advance over ISO 9000 regarding the use of innovative work practices.
\end{abstract}

\section{Key words}

ISO 9001, work organization, human resource management, empirical study, quality management

\footnotetext{
+ The authors are thankful to the Institute of Statistics of Navarre for the data used in the paper and to the Government of Navarre and the Spanish Ministry of Education and Science (SEC2007 -66511) for the funding provided.

*Corresponding author. Universidad Pública de Navarra, Departamento de Gestión de Empresas, Campus de Arrosadía, 31006 Pamplona - España. Telephone: 34948 169377. Fax: 34948 169404.E-mail: abayom@unavarra.es.
} 


\section{Introduction}

During the last three decades, firms around the world have witnessed the emergence and diffusion of a series of non-technological innovations designed to improve management practices within organizations. One of these is Quality Management, which has unquestionably become of particular significance and prevalence in all activity sectors. Quality Management involves the adoption of a philosophy that comprises a focus on customers and the continuous improvement of production processes, as well as on the implementation of a range of techniques and approaches, such as statistical process control (SPC), seven basic tools, quality function deployment (QFD), etc. The academic literature on Quality Management has provided considerable empirical evidence of the positive impact that the adoption of different quality management systems and models has had on various dimensions and measures of firm performance (Samson and Terziovski, 1999; Sun, 2000; Prajogo and Sohal, 2003; Tarí and Sabater, 2004).

Firms develop their ideas and practices of Quality Management within two main frameworks (Martínez-Costa et al., 2008): on the one hand, the implementation of Quality Management systems, the best example of which may be the system based on ISO 9000 quality standards series; and on the other, the scheme provided by excellence models (or Total Quality Management Models) (Sadikoglu and Zehir, 2010), the most prevalent of which in Europe is the EFQM model.

Another significant development in recent years is the expansion of flexible systems of work organization (Osterman, 1994; Gittleman et al., 1998; Handel y Levine, 2004). These systems comprise a series of practices whose principal aim is to transfer high decision-making power to workers and foster their involvement in the activities of the company by means of (both ascending and descending) information- 
exchange and communication between employer and employees. Together with this, workers must become more multi-skilled and capable of performing a greater number and wider variety of tasks; this also requires that employees receive more information about the general operations framework whereby the firm carries out its activities. As a consequence, decisions are taken by those that detect problems and, therefore, have a more refined knowledge of their potential causes. This enables the firm to implement a faster response and to avail of greater flexibility when dealing with unexpected circumstances. Moreover, as long as these practices are conceived as employee-centred, they may be expected to lead to increased motivation and job satisfaction and greater commitment to the employer.

Practices commonly included in these systems are self-directed teams, problemsolving groups (such as quality circles) and information meetings among employers and employees. Their positive effects on productivity and firm performance are reflected in the conclusions to many studies based on samples of firms from different sectors (Black and Lynch, 2001; Cappelli and Neumark, 2001; Richard and Johnson, 2001; Way, 2002; Black and Lynch, 2004).

In spite of the significance acquired by Quality Management and flexible work practices, the relationship between the two has rarely been addressed in the research literature. Nevertheless, the scarce empirical evidence available suggests that these two innovations tend to be implemented jointly and that they could be part of a common approach to business management (Wood, 1999; Bayo-Moriones and Merino, 2001; de Menezes and Wood, 2006).

The limitations of existing research underscore the need for more focused analysis of the influence that Quality Management may have on the adoption of flexible work systems. This is of particular relevance in relation to ISO 9000 and EFQM, whose 
relationship with innovative work practices has received little or no attention in empirical research terms.

The purpose of this paper is to explore the impact that these two approaches to Quality Management have on the incidence of flexible work systems. Furthermore, the intention is to evaluate the magnitude of the effects of these two systems on new work practices. To this end, the information gathered through a survey carried out in a final valid sample of 665 Spanish business establishments with at least 20 employees from the manufacturing, building and service sectors is analysed.

This paper contributes to the existing research literature in several ways. First and foremost, it provides additional evidence regarding the influence of Quality Management on human resources management and, more particularly, on the incidence of flexible work practices. Secondly, so far as we know, this is the first paper to consider the influence of the two approaches used by nearly all firms that decide to implement Quality Management in their activities, which enables us to explore whether or not the effects of both approaches on work organization are the same. Finally, the sample of companies analysed is not limited to a particular sector, which increases the significance of the conclusions reached, and may enable the application of such innovative practices to a larger number and wider variety of firms.

The paper is structured as follows. The following section studies the implications of Quality Management for work organization from a theoretical perspective. Several hypotheses regarding the impact of ISO 9000 and EFQM on the adoption of flexible work practices are then formulated. Section three describes the main characteristics of the database used in the empirical analysis; the variables used in the estimations are defined and the methodology used to test such hypotheses explained. Section four sets out and discusses the results obtained in the estimations of the empirical models. 
Finally, the main conclusions are presented.

\section{Quality management and work organization practices}

Since the very beginning of the quality movement, the importance given to different aspects of human resources management as key elements within the models and paradigms of Quality Management has been quite remarkable. Thus, the pioneers in this field already included some of these aspects in their work. For instance, when enunciating his famous "fourteen points for the transformation of the American industry”, Deming (1982) explicitly mentioned some ideas such as the implementation of job training (point 6), the implementation of a vigorous program of education and self-improvement (point 13) or the involvement of company staff in order to accomplish transformation (point 14). Crosby (1979) also made reference to the need for teams of workers in improving quality, while Juran (1990) emphasised training supply, team creation and achievement recognition in his methodology for quality improvement.

Later academic literature on the topic has been marked by a concern to define the concept of Quality Management, which has led to the inclusion of points directly related to human resource management in all the proposals made in this area. Dean and Bowen (1994) consider teamwork to be one of the three basic principles of Quality Management, along with the continuous improvement of production processes and customer orientation. Despite acknowledging significant differences in the definition of the Quality Management concept, Dale et al. (1994) discern several common key elements such as education and training, teamwork and employee involvement. Other theoretical works, such as those by Hackman and Wageman (1995), Waldman (1994), Wruck and Jensen (1994) and Wilkinson et al. (1998), as well as other empirical works, such as those by Flynn et al. (1994), Ahire et al. (1996), Black and Porter (1996), 
Merino (2003) and Quazi and Jacobs (2004), pursue similar lines of argument.

The ideas, principles and practices of Quality Management have been adopted by firms in the Western world in two principal ways. On the one hand, such implementation is effected through the adoption of management systems, mainly that based on the ISO 9000 series (Lo et al., 2009). The ISO 9000 series is a set of standards that addresses the quality of a company's processes. The philosophy underlying these standards for process documentation is that companies with well-established operations and processes will be in the best position to influence the quality of their products and services (Withers et al., 1997).

The International Standard specifies requirements for a quality management system where an organisation needs to demonstrate its ability to ensure that its product consistently meets customer applicable regulatory requirements and to address customer satisfaction through the effective application of the system, including processes for continual improvement and the prevention of non-conformity. Significant emphasis is placed on the use of measurement and analysis of results. The framework for ISO 9000 appears in Figure I.

\section{INSERT FIGURE 1 ABOUT HERE}

Information on the diffusion of ISO 9000 certification throughout the world is widely available (Marimón et al., 2006). The “ISO Survey of Certifications 2007” shows that the number of firms certified according to ISO 9000:2000 standards increased from 497,919 in December 2003 to 951,486 in December 2007 around the world. East Asia and the European Union were the geographical areas with the highest degree of implementation (ISO 2008).

On the other hand, some firms have opted to develop a management model taking the EFQM model as the frame of reference - that is, the excellence model designed by 
the European Foundation for Quality Management. The EFQM is a non-prescriptive framework (see figure 2) comprising nine criteria that address all the activities and interested parties/stakeholders in an organisation, enabling the assessment of progress towards excellence.

\section{INSERT FIGURE 2 ABOUT HERE}

Since, unlike ISO 9000, there are no external certifications to quantify its level of implementation, the data regarding the implementation of the EFQM model is less precise. Some data on the firms that take part in annual quality awards based on the model and granted by different organizations are available. However, this amounts to a very small proportion of the total number of firms that might be working according to this model. Although the idea is that its implementation is clearly inferior to ISO 9000, its influence in the area the Quality Management is undeniable, in that it is a model fostered by the main institutions devoted to quality support and promotion.

Based on a booklet from the British Quality Foundation, Russell (2000) analysed the linkage and contribution of ISO 9000 (ISO 9000:2000, in particular) to excellence. Such links are presented in Figure 3. The most significant overlap between ISO 9000 and EFQM may be discerned in "processes”. Policy Strategy and Customer Results also show considerable congruence. On the other hand, however, Society Results are not reflected in ISO 9000.

\section{INSERT TABLE 1 ABOUT HERE}

In principle, these two models are not exclusive; in fact, it has been argued that excellence models constitute the final stage in the journey towards quality and, to a certain extent, their adoption may be regarded as the next step to be taken by a firm that has already managed to implement a Quality Management system (Sun, 2000; Martínez-Lorente and Martínez-Costa, 2004). Although this may be the natural path 
towards excellence, , in practice, there are organizations working with the EFQM framework that have not previously established a certified Quality Management system.

\subsection{ISO 9000 and flexible work practices}

The ISO 9000 standard does not attribute any special significance to topics related to human resources management (Tummala and Tang, 1996; Gotzamani and Tsiotras, 2001). Regarding this issue, its 1994 version makes reference only to training. Thus, clause 4.18 states that “the supplier shall establish and maintain documented procedures for identifying the training needs and provide for the training of all personnel performing activities affecting quality. Personnel performing specific assigned tasks shall be qualified on the basis of appropriate education, training, and/or experience, as required. Appropriate records of training shall be maintained”.

Subsequent revision led to the formulation of the standard currently in force, ISO 9001:2000. This new version includes a marked emphasis on human resources management, as devoting clause 6.2 in section 6 ("Resource Management”) to the subject: "personnel performing work affecting product quality shall be competent on the basis of appropriate education, training, skill and experience”. In addition, clause 6.2.2 states that "the organization shall:

a) determine the necessary competence of personnel performing work affecting product quality.

b) provide training or take other actions to satisfy these needs.

c) evaluate the effectiveness of these actions taken.

d) ensure that its personnel are aware of the importance of their activities and how they contribute to the achievement of the quality of the objectives and e) maintain appropriate records of education, training, skills and experience”. 
Moreover, in section 5 on "Management Responsibility”, clause 5.5.3 states that “top management shall ensure that appropriate communication processes are established within the organization and that communication takes place regarding the effectiveness of the quality management system”, measures that are closely related to human resources management in the firm.

Analysis of the above-mentioned points shows that ISO 9000 standard repeatedly insists on such aspects as training and competences, including the need to evaluate the effectiveness of actions taken in this area. Moreover, while the need to promote employee involvement may be acknowledged in point “d”, no specific actions are detailed in that regard.

However, the emphasis on such aspects would appear to be clearer in the declaration of principles that underlie and inspire the standard. Thus, principle 3 is entitled "People involvement”, and states that "the organisation shall ensure that its personnel are aware of the relevance and importance of their activities and how they contribute to the achievement of quality objectives.”

Other principles, such as those related to leadership and to continuous improvement, also make explicit reference to the need for employee involvement in achieving company objectives and continuous improvement. In this context, Singh (2008) regards “capable employees” as one of the six key management practice constructs. "Capable employees” are fully trained for the work they perform; know their roles and goals; are aware of how the quality policies of the organization affect their jobs; have a role in formulating organizational and work plans; have their development and motivation fostered; and continuously improve their work output.

In summary, it may be concluded that the requirements of the ISO 9001:2000 standard are modest with regard to promoting employee involvement and that they 
focus almost exclusively on aspects related to training and competencies. Nevertheless, the principles underlying the standard clearly stress the need to increase employee participation, improve communication flows, and to value employees' contributions. In the first empirical paper on this topic to our knowledge, based on a sample of firms in the USA, India, China and Mexico, Rao et al. (1997) concluded that most of the companies with an ISO 9000 certified quality system had implemented human resources management systems to a greater extent, which included measures to foster employee involvement and empowerment. For their part, Quazi and Jacobs (2004) found a positive relationship between certification according to the ISO 9000 standard and several indicators related to personnel training and human resources development. Unfortunately, given the small sample size involved, their results do not lend themselves to direct generalization.

\subsection{TQM and flexible work practices}

TQM or excellence models are much clearer than ISO 9000 standards as far as human resources management is concerned. Human resources management is considered a key area in the management system of a firm; and employee involvement and work organization based on teams are important aspects of such models (Mandal et al, 1998).

These models are especially appealing to those interested in human resources management. First of all, because this is one of the theoretical dimensions which is encompassed by TQM models: evaluation models and measurement studies on TQM

incorporate human practices (Tarí and Sabater, 2006). Secondly, because in real life, the success or failure of TQM implementation depends on how the employees at all hierarchical levels deal with it (Hill and Wilkinson, 1995). TQM and human aspects 
need to be integrated so as to ensure performance improvements (Zu et al., 2010). Extensive changes are required in human resource management. Wilkinson (2004) states that the congruence of the Total Quality Management philosophy with many aspects of human resources management should come as no surprise, because the usual point of view on human resources management is that this one is contingent to firm strategy. Since the commitment to Quality Management is usually an important element of most organizational strategies, the relationship is quite evident. Thirdly, human resources are necessary for quality performance, the core performance target for TQM (Kaynak, 2003).

This positive relationship between TQM and higher levels of empowerment and involvement, wherein employees take decisions and are responsible for results, has emerged in several empirical articles. Wilkinson et al. (1998) explored this relationship in six manufacturing companies in the UK and their findings stressed the importance of employees and the multidimensional nature of employee involvement under TQM. In relation to a sample of American and European companies operating in Greece, Kufidu and Vouzas (1998) likewise concluded that in their efforts to move towards a quality management approach, firms tend to adopt constructive human resource management practices. For a sample of Spanish manufacturing plants, Bayo-Moriones and Merino (2001) found a positive effect of quality tools (failure mode and effect analysis, statistical process control, etc.) on the incidence of work practices such as job rotation, job autonomy, teamwork and improvement groups.

Not only do the results in Tarí and Sabater (2006) show that firms with a wider implementation of TQM performance display a higher concern for empowerment, but also that TQM success depends to a great extent on this human resource management factor. Similar findings appear in Jiménez-Jiménez and Martínez-Costa (2009). Their 
results show both that HRM practices such as job design and teamwork are positively related to TQM and that they have a positive effect on company performance.

Focusing on the EFQM model, criterion 3 ("People”), one of the nine in which the model is structured, makes reference to "how the organization manages, develops and releases the full potential of their people at an individual, team-based and organisationwide level”.

This criterion unfolds in five subcriteria: planning, management and improvement of human resources; identification, development, and maintenance of the knowledge and abilities of people in the organization; the involvement and empowerment of people in the organization; the existence of dialogue between people and organization; and, finally, the reward, recognition and care of the people in the organization.

In addition, all of this is reinforced with criterion number 7, "People Results", which states that “excellent organizations comprehensively measure and achieve outstanding results with respect to their people”. With this idea in mind, a series of perceptual and performance indicators is proposed, so firms can put this criterion into practice.

\subsection{Hypotheses}

From the preceding analysis of the ISO 9000 standard and the EFQM model, it may be deduced that both systems contribute, to a greater or lesser extent, to the use of mechanisms within the firm that are designed to grant employees more responsibility in their work and to promote greater participation in the running of the firm.

However, it is also possible to conclude that the EFQM model attributes greater significance to human resources management than the ISO 9000 standard. Its principles tend to grant employees more demanding assignments and to empower them in their job 
performance in more intensive ways. This corresponds closely to the underlying philosophy of flexible work practices. For this reason, organizations working with the EFQM model as a management frame of reference may be expected to implement such work organization practices more often than those working with a certified quality system according to the ISO 9000 standard.

The line of argument traced above prompts the formulation of the following hypotheses, which are then tested in the empirical section of this paper:

H1: Firms that have implemented a certified quality system according to the ISO 9000 standard use flexible work organization practices to a greater extent than those that have not implemented it.

H2: Firms that have adopted the EFQM model as a management frame of reference use flexible work organization practices to a greater extent than those that have not adopted it.

H3: The impact of the EFQM model on the use of flexible work organization practices is greater than the impact of ISO 9000 .

\section{Methodology}

\subsection{Data}

The data used in the empirical analysis of the paper was obtained from a survey of business establishments conducted by the Statistical Institute of Navarre (Spain) in 2004. The target range for the survey comprised all the establishments in the region of Navarre with twenty or more workers in all sectors of economic activity. The sample was stratified by size and sector. Establishments with a lower number of employees were excluded because they usually show more variable and less formal patterns of work organization, which makes it more difficult to get reliable responses in relation to 
the way in which work is organized (Cappelli and Neumark, 2001).

The questionnaire was sent by post to the general manager of the establishment. It was answered by telephone, fax or e-mail, by the general manager of the establishment or another manager designated by him/her because of the latter's familiarity with the issues dealt with in the questionnaire. The reason for offering firms these three modes of response was to facilitate participation in the survey by allowing the respondent to choose the mechanism most suitable to him. The response rate was 98.77\%. This high response rate is due to both the range of response modes and to the fact that the survey was conducted by the Regional Government of Navarre and participation was compulsory under the threat of a fine. The high response rate guarantees the representativeness of the sample and ensures there is no significant bias in response and non-response patterns.

On the other hand, given the small number of agriculture firms in the sample and the particularities of this sector of activity, such firms have been excluded from our analysis. This led to an initial sample of 695 establishments, which was again reduced to 665 because of missing data in certain variables.

\subsection{Variables}

Dependent variables. The flexible work practices considered in our empirical analysis are representative of the practices that usually appear in the literature pertinent to this research field (see, for example, Osterman, 1994; Gittleman et al., 1998; Cappelli and Neumark, 2001; Bresnahan et al., 2002; Black and Lynch, 2004). They share the characteristic of being mechanisms through which the firm encourages employee involvement and information sharing either through upwards, downwards or lateral communication and decision-making. 
Five variables which illustrate the incidence of flexible work practices have been taken into account: (1) the percentage of workers who take part in groups set up to solve specific problems, such as continuous improvement groups or quality circles; (2) the percentage of workers who belong to autonomous work teams for the performance of ordinary tasks; (3) the percentage of workers who participate in autonomous work teams for the development of new projects; (4) a dummy variable that reflects the existence of a formal system to collect and track suggestions made by workers; and (5) a dummy variable that reflects whether the firm's top management meets regularly with its workers to provide them with information about the performance and plans of the firm.

Independent Variables. Two variables are used to measure the adoption of quality systems or models. One is a binary variable that indicates whether or not the firm has a certified quality system according to the ISO 9000 standard. The other is also a binary variable that indicates whether or not the firm is involved in the evaluation process according to the EFQM model, as a way to ensure that the firm is effectively working in such a framework.

All the estimations have included several control variables used in the literature with regard to determinant factors in the adoption of flexible work practices (Gittleman et al., 1998; Guthrie et al., 2002). The size of the establishment has been measured through several binary variables depending on intervals of worker numbers, ranging from 20 to 49, from 50 to 99, and from 100 to 249 . The dummy variable capturing 250 and more employees has been omitted from the analysis, so the coefficients for the dummy size variables included should be interpreted in comparison with the largest firms.

A dummy variable indicating whether or not the establishment is part of a multinational group of firms has also been taken into account. The influence of trade unions on the 
adoption of flexible work practices has been considered with the introduction of a dummy variable that takes value one if there is a specific collective agreement between the employer and workers' representatives to regulate work conditions at the establishment or firm. Finally, the industry sector has been taken into account by dummy variables that indicate if the economic activity of the establishment is manufacturing, building or services (omitted category).

Table 2 displays the mean and standard deviation for all variables. As can be seen, there is significant variability in the coverage of improvement groups as well as autonomous teams, which is reflected in high standard deviations as compared to means. Table 2 also reports the means for all variables in line with the presence or not of ISO 9000 and the presence or not of EFQM. That the incidence of these two quality systems differs considerably depending on firm characteristics such as size, industry and multinational nature is noteworthy. These patterns underline the need to control for all these factors in our estimations.

INSERT TABLE 2 ABOUT HERE

Table 3 displays the correlation matrix and shows very high correlation coefficients among the five flexible work organization practices, suggesting that they have been implemented jointly. The correlation matrix also confirms the correlations between ISO, EFQM and firm characteristics outlined above.

INSERT TABLE 3 ABOUT HERE

\subsection{Estimation}

The empirical models have been selected according to the nature of the dependent variables. Since they are measured through censored variables, tobit models have been estimated to analyse the incidence of improvement groups, autonomous work teams for 
the accomplishment of daily tasks, and autonomous work teams for new project development. Tobit models are used when the dependent variable takes values only in a limited range (Greene, 2002). This is the case of the abovementioned variables, since they are percentages and, therefore, vary between zero and one hundred. In the case of the binary variables relating to suggestion systems and informative meetings between top management and employees, probit models have been applied. In order to verify the third hypothesis, a Wald test has been run for all the models.

\section{Discussion of Results}

Table 4 presents the results obtained in the estimation of the models concerning the following variables: percentage of employees in improvement groups; percentage of employees in autonomous teams for ordinary tasks; and percentage of employees in autonomous teams for new project development.

\section{INSERT TABLE 4 ABOUT HERE}

First, as may be observed, there is a positive and statistically significant relationship between the adoption of a quality system according to ISO 9000 and the percentage of employees that take part in improvement teams. The same effect is detected concerning the adoption of the self-assessment EFQM model. Therefore, it is possible to say that hypotheses 1 and 2 are verified in relation to this work organization practice. However, the same does not happen with the third hypothesis. The Wald test results show that there are no significant differences between the impact of the adoption of ISO 9000 and the impact the adoption of EFQM on the percentage of employees that take part in improvement teams.

The second column in Table 4 displays the results obtained from the second tobit model testing the hypotheses in relation to autonomous teams for the performance of 
ordinary tasks. Unlike what happened with the percentage of workers that participate in improvement teams, neither of the first two hypotheses is verified, which implies that neither ISO 9000 nor EFQM seems to influence the incidence in the firm of autonomous teams as a work organization formula. This result is quite surprising, since this is a relatively common measure taken to promote employee empowerment, one of the key elements in excellence models so far as human resources management is concerned. Organizing ordinary duties in autonomous teams is far from an easy task, due to the mind-set change required at all levels in the organization, regardless of whether or not the firm is involved in the implementation of a quality management system or model. The third hypothesis is likewise unverified, since there are no differences between the relationship between ISO 9000 or EFQM and the dependent variable.

In the third column in Table 4, the estimated tobit models present the relationships between ISO 9000 and EFQM and autonomous teams for new project development. Unlike the previous model, in this case there is a significant connection between the adoption of the EFQM model as a frame of reference for improvement and this work practice. This does not happen with the ISO 9000 variable. In addition, the Wald test confirms it with a small but significant difference in the impact on this variable for both systems in favour of EFQM. This result is consistent with the arguments made by quality movement supporters (Dean and Bowen, 1994; Hackman and Wageman, 1995). It also corroborates the idea that EFQM gives more importance to the empowerment of human resources than ISO 9000. It is quite evident that it is easier to promote teamwork for new project development, in which the contribution of ideas and solutions is a must, than for the performance of ordinary task which are usually more standardized and less prone to creativity. 


\section{INSERT TABLE 5 ABOUT HERE}

Table 5 presents the results obtained in the two probit models estimated to explain the implementation of two of the work organization practices included in this paper: the existence of a suggestion system, and the existence of informative meetings between top management and employees.

Regarding the existence of a formal system to collect and track employees’ suggestions, there is a positive and very significant relationship with both ISO 9000 and EFQM. Therefore, the first two hypotheses are clearly confirmed in the case of this work practice. Firms working with Quality Management systems and models use the suggestion systems to involve their employees in the improvement process, which is absolutely in tune with the ideas of the quality movement. With respect to the third hypothesis, it is observed that there are no significant differences between ISO 9000 and EFQM concerning their impact on the existence or absence of a collecting and tracking system for employees’ suggestions.

The results in relation to informative meetings are different. Firms working under the EFQM model use such meetings more often, as a way to improve communications between top management and employees, a measure which is not adopted in firms that are certified according to the ISO 9000 standard. Hypothesis 2 and 3 are confirmed in this regard, whereas hypothesis 1 is not.

\section{Conclusions and Suggestions for Future Research}

Since the beginning of the quality movement, the importance of certain human resources management practices, especially those related to work organization, has always been pointed out as a key element in the endeavour to reach improvement goals in the organization. Thus, it is felt that certain practices, such as those that promote 
employee involvement or empowerment, work organization around teams, or those that generate better communication within the organization, should be implemented at the same time as Quality Management systems or models.

Generally speaking, there are two ways in which firms in Western countries are developing Quality Management issues. On the one hand, the implementation and certification of quality systems according to the ISO 9000 standard undoubtedly comprise the most popular methodology. On the other hand, evaluations based on the European Foundation for Quality Management Model (EFQM) are gaining ground in improvement processes.

The objective of this paper has been to analyse the impact that the two Quality Management approaches have on five specific work organization practices. With this purpose in mind, five empirical models have been estimated in order to test three hypotheses: the first, about the relationship of ISO 9000 and such work practices; the second, about the impact of EFQM on such work practices; and the third, to explore which of the two Quality Management models, ISO 9000 or EFQM, has greater influence on the incidence of the practices under review.

As established by the hypotheses formulated in the theoretical part of the paper, the empirical findings show that the presence of quality models ISO 9000 and EFQM has a significant and positive effect on the adoption of flexible work practices. In the case of the ISO 9000 standard, this effect takes place through improvement groups and the implementation of suggestion systems. Regarding the EFQM model, in addition to these practices, there is also a significant correlation with the percentage of employees that take part in work teams for new project development and on the organization of informative meetings between top management and employees.

From these results it may be concluded that there is some disparity between the 
most commonly used models for Quality Management, ISO 9000 and EFQM, as far as their impact on the individual use of flexible work practices is concerned. It seems clear that firms that have adopted the EFQM model are more inclined to implement these practices, with the exception of autonomous work teams for ordinary tasks. Therefore, in our empirical analysis, the hypothesis that the EFQM model is more advanced than ISO 9000 with regard to fostering the implementation of innovative practices in work organization is confirmed.

Our results confirm that the high significance attributed to aspects of human resource management since the beginning of the quality movement (Crosby, 1979; Deming, 1982; Juran, 1990) is not merely rhetorical, but is reflected in reality. That the requirements established in the models and frameworks of ISO 9000 and EFQM are fulfilled in practice is also clear. Moreover, our findings are consistent with those reached in previous empirical research analyzing the relationship between quality management and flexible work practices. For example, articles such as Wilkinson et al. (1998), Kufidu and Vouza (1998), Bayo-Moriones and Merino (2006) and Tarí and Sabater (2006) found that in those firms where the degree of implementation of quality management was greater, there was a higher incidence of work practices aimed at promoting employee involvement and empowerment.

Of the five flexible work practices considered here, teamwork for ordinary tasks is the only one that is not associated with the development of Quality Management in the firm. The implementation of practices designed to promote employee involvement and to improve both upwards and downwards communication (improvement groups, informative meetings and suggestion systems) is clearly influenced by the adoption of Quality Management systems. However, Quality Management does not have the same effect on teamwork whose purpose is to grant employees greater autonomy and 
decision-making power.

A pertinent question in this regard is why practices that promote employee involvement in the firm are more clearly associated with Quality Systems and models than those practices that assign them greater responsibilities, if the theoreticians of the quality movement assign similar importance to both. There are several possible explanations for this fact.

First of all, the results obtained may imply that the decision to implement such work practices depends more on the features of production process or the characteristics of employees than on the adoption of a particular management system, no matter how much emphasis is placed by top management. Secondly, that employee involvement practices present fewer difficulties in terms of implementation should also be acknowledged. Unlike work teams, their implementation does not involve a radical change in the everyday production processes within the organization. In addition, the benefits and improvements in products and processes obtained after the implementation of practices such as improvement groups may be more visible and immediate.

The evidence presented in this paper may also contribute to the debate regarding the potential value and use of developing Quality Management on the basis of quality systems or excellence models (Gotzamani and Tsiotras, 2001; Martínez-Lorente and Martínez-Costa, 2004; Heras et al., 2006; Martínez-Costa et al., 2009). Assuming that both concepts of quality are perfectly compatible and even complementary, the results obtained suggest that excellence models and their greater impact on flexible work organization practices may better contribute to increasing the added value of firms than the mere fulfilment of the requirements set out in a standard. If such models promote the adoption of practices that the human resources management literature regards as leading to better firm performance, their contribution might be greater than if all that the 
firm does is accomplish certain standards, no matter how valid they may be.

Although the empirical analysis carried out here is based on data from a significant number of establishments in the manufacturing, building and service sectors, there are some limitations in the paper that might be mitigated in future research work. Firstly, since cross-sectional data is used, it is impossible to establish the causal direction between ISO 9000 and EFQM implementation and the use of flexible work organization practices. Secondly, the database used does not include information on the implementation characteristics of the management systems or models within firms (in terms of intensity, time, groups of workers covered, etc.).

These limitations and our findings suggest several lines for future research. Firstly, the analysis of the impact of ISO 9000 and EFQM needs to be applied to other human resource management practices apart from work organization. For example, selection, training and compensation are core areas in personnel management that could vary depending on the kind of quality management approach taken by the firm.

Secondly, the use of longitudinal data would enable more exact analysis of the relationships between ISO 9000 and EFQM and flexible work organization practices. There is a clear need to disentangle the nature of the association between these two variables in order to know whether they tend to be implemented simultaneously or whether one may be adopted earlier than the other.

Thirdly, a logical complement of our research is to analyze the performance effect of flexible work practices in both ISO 9000 and EFQM contexts. The findings would be extremely valuable for practitioners and would help ascertain whether or not the relationships found in our paper are rooted only in performance considerations.

Fourthly, all employees have been dealt with uniformly in this paper; that is, the adoption of flexible work practices has been considered globally. It would be interesting 
to analyze whether the findings in our paper occur for all the different groups of workers in the firm: production workers, technicians, supervisors, middle managers, etc. Finally, the effects of Quality Management on employees, regarding aspects such as job satisfaction or job intensification have scarcely been studied. Although this was not the objective of the paper, it clearly opens the door for future research on the mediating role flexible practices may play in the analysis of the impact of Quality Management on employees. Given that the results obtained show that the two Quality Management systems and models analysed are linked to the adoption of innovative work practices, the effect that these work systems have on employee well-being will likewise determine the influence of Quality Management on them. 


\section{References}

Ahire, S.L., Golhar, D., Waller, M.A., 1996. Development and Validation of TQM Implementation Constructs. Decision Sciences, 27(1), 23-56.

Bayo-Moriones, A., Merino, J., 2001. Quality management and high performance work practices: Do they coexist? International Journal of Production Economics, 73(3), 251-259.

Bergenhenegouwen, L., de Jong, A., \& de Vries, H. J. (2002). 100 frequently asked questions on the ISO 9000:2000 series. Milwaukee, WI: ASQ Quality Press.

Black, S.E., Lynch, L.M., 2001. How to compete: the impact of workplace practices and information technology on productivity. Review of Economics and Statistics, 83(3), 434-445.

Black, S.E., Lynch, L.M., 2004. What's driving the new economy?: The benefits of workplace innovation. Economic Journal, 114(493), F97-F116.

Black, S.A., Porter, L.J., 1996. Identification of the Critical Factors of TQM. Decision Sciences, 27(1), 1-21.

Bresnahan, T.F., Brynholfsson, E., Hitt, L.M., 2002. Information technology, workplace organization, and the demand for skilled labor: firm-level evidence. Quarterly Journal of Economics, 117(1), 339-376.

Cappelli, P., Neumark, D., 2001. Do “high-performance” work practices improve establishment-level outcomes? Industrial and Labor Relations Review, 54(4), 737775.

Crosby, P.B., 1979. Quality is Free. New York, NY: McGraw Hill.

De Menezes, L.L., Wood, S., 2006. The reality of flexible work systems in Britain. International Journal of Human Resource Management, 17(1), 106-138. 
Dean, J.W., Bowen, D.E., 1994. Management theory and total quality: improving research and practice through theory development”. Academy of Management Review, 19(3), 392-418.

Deming, W.E., 1982. Out of the crisis. Quality, Productivity and Competitive Position. Cambridge, MA: Cambridge University Press.

Flynn, B.B., Schroeder, R.G., Sakakibara, S., 1994. A Framework for Quality Management Research and an Associated Measurement Instrument. Journal of Operations Management, 11(4), 339-366.

Gittleman, M., Horrigan, M., Joyce, M., 1998. “Flexible” work practices: evidence from a nationally representative survey. Industrial and Labor Relations Review, 52(4), 99-115.

Godard, J., 2004. A critical assessment of the high-performance paradigm. British Journal of Industrial Relations, 42(2), 349-378.

Gotzamani, K.D., Tsiotras, G.D., 2001. An empirical study of the ISO 9000 standards contribution towards total quality management. International Journal of Quality and Reliability Management, 21(10), 1326-1342.

Greene, W.H., 2002. Econometric Analysis, 5th ed. Upper Saddle River: Prentice Hall Guthrie, J.P., Spell, C.S., Nyamori, R.O., 2002. Correlates and consequences of high involvement practices: the role of competitive strategy. International Journal of Human Resource Management, 13(1), 183-197.

Hackman, R., Wageman, R., 1995. Total Quality Management: Empirical, Conceptual and Practical Issues. Administrative Science Quarterly, 40(2), 309-342.

Handel, M.J., Levine, D.I., 2004. Editor's Introduction: The Effects of New Work Practices on Workers. Industrial Relations, 43(1), 1-43. 
Heras, I., Arana, G., Casadesús, M., 2006. A Delphi study on motivation for ISO 9000 and EFQM. International Journal of Quality and Reliability Management, 23(7), 807-827.

Hill, S., Wilkinson, A., 1995. In search of TQM. Employee Relations, 17(3), pp. 8-25. ISO, 2008. The ISO Survey of Certifications 2007. Geneva: ISO.

Jiménez-Jiménez, D., Martínez-Costa, 2009. The performance effect of HRM and TQM: a study in Spanish organizations. International Journal of Operations \& Production Management, 29(12), 1266-1289.

Juran, J.M., Gryna, Jr., F.M., Bingham, Jr., R.S., 1990. Quality Control Handbook. New York: McGraw Hill.

Kaynak. H. (2003). The relationship between total quality management practices and their effects on firm performance. Journal of Operations Management, 21(4), 405435.

Kufidu, S., Vouzas, F., 1998. Human resource aspects of quality management: evidence from MNEs operating in Greece. International Journal of Human Resource Management, 9(5), 818-830.

Lo, C.K.Y., Yeung, A.C.L., Cheng, T.C.E., 2009. ISO 9000 and supply chain efficiency: empirical evidence on inventory and account receivable days. International Journal of Production Economics, 118, 367-374.

Mandal, P., Howell, A., Sohal, A.S., 1998. A systemic approach to quality improvements: The interactions between the technical, human and quality systems. Total Quality Management, 9(1), 79-100.

Marimón, F., Casadesús, M., Heras, I., 2006. ISO 9000 and ISO 140000 standards: an international difussion model. International Journal of Operations and Production Management, 26(2), 141-165. 
Martínez Costa, M., Martínez Lorente, A.R., Choi, T.Y., 2008. Simultaneous consideration of TQM and ISO 9000 on performance and motivation: an empirical study of Spanish companies. International Journal of Production Economics, 113, 23-29.

Martínez Costa, M., Choi, T.Y., Martínez Lorente, A.R., 2009. ISO9000/1994, ISO 9001/2000 and TQM: the performance debate revisited. Journal of Operations Management, 27(6), 495-511.

Martínez Lorente, A.R., Martínez Costa, M., 2004. ISO 9000 and TQM: substitutes or complementaries? An empirical study in industrial companies. International Journal of Quality and Reliability Management, 21(3), 260-276.

Merino, J., 2003. Quality Management Practices and Operational Performance: Empirical Evidence for Spanish Industry. International Journal of Production Research, 41(12), 2763-2786.

Osterman, P., 1994. How common is workplace transformation and who adopts it? Industrial and Labor Relations Review, 47(2), 173-188.

Prajogo, D.I., Sohal, A.S., 2003. The relationship between TQM practices, quality performance and innovation performance. An empirical examination. International Journal of Quality and Reliability Management, 20(8), 901-918.

Quazi, H.A., Jacobs R.L., 2004. Impact of ISO 9000 certification on training and development activities: An exploratory study. International Journal of Quality and Reliability Management, 21(5), 497-517.

Rao, S.S., Raghu-Natham, T.S., Solis, L.E., 1997. Does ISO 9000 have an effect on quality management practices? An international empirical study. Total Quality Management, 8(6), 335-346. 
Richard, O.C., Johnson, N.B., 2001. Strategic human resource management effectiveness and firm performance. International Journal of Human Resource Management, 12(2), 299-310.

Russell , S., 2000. ISO9000:2000 and the EFQM Excellence Model: competition or cooperation. Total Quality Management, 11(4/5\&6), 657-665.

Sadikoglu, E., Zehir, C. (2010). Investigating the effects of innovation and employee performance on the relationship between total quality management. International Journal of Production Economics. doi:10.1016/j.ijpe.2010.02.013

Samson, D., Terziovski, M., 1999. The relationship between total quality management practices and operational performance. Journal of Operations Management, 17(4), 393-409.

Singh, P.J., 2008. Empirical assessment of ISO 9000 related management practices and performance relationships. International Journal of Production Economics, 113, 4059.

Sun, H., 2000. Total quality management, ISO 9000 certification and performance improvement. International Journal of Quality and Reliability Management, 417(2), 168-179.

Tarí, J.J., Sabater, V., 2004. Quality tools and techniques: Are they necessary for quality management? International Journal of Production Economics, 92, 267-280.

Tarí, J.J., Sabater, V., 2006. Human aspects in a quality management context and their effects on performance. International Journal of Human Resource Management, 17(3), 484-503.

Tummala, V.M.R., Tang, C.L., 1996. Strategic quality management, Malcolm Baldrige and European quality awards and ISO 9000 certification: core concepts and 
comparative analysis. International Journal of Quality and Reliability Management, 13(4), 8-38.

Waldman, D.A., 1994. The Contributions of Total Quality Management to a Theory of Work Performance. Academy of Management Review, 19(3), 510-536.

Wall, T., Wood, S., 2005. The romance of human resource management and business performance, and the case for big science. Human Relations, 58(4), 429-462.

Way, S., 2002. High performance work systems and intermediate indicators of firm performance within the US small business sector. Journal of Management, 28(6), 765-785.

Wilkinson, A., 2004. Quality and the human factor. Total Quality Management, 15(8), 1019-1024.

Wilkinson, A., Redman, T., Snape, E., Marchington, M., 1998. Managing with Total Quality Management. Theory and Practice. London: MacMillan Business.

Withers, B.E., Ebrahimpour, M. and Hikmet, N., 1997. An exploration on the impact of TQM and JIT on ISO 9000 registered companies. International Journal of Production Economics. 53, 209-216.

Wood, S., 1999. Getting the measure of the transformed high-performance organization. British Journal of Industrial Relations, 37(3), 391-417.

Wruck, K.H., Jensen, M.C., 1994. Science, Specific Knowledge, and Total Quality Management. Journal of Accounting and Economics, 18(3), 247-287.

Zu, X., Robbins, T.L., Fredenhall, L.D., 2010. Mapping the critical link between organizational culture and TQM/Six Sigma practices. International Journal of Production Economics, 123, 86-106. 
Figure 1. ISO 9000:2000 scheme

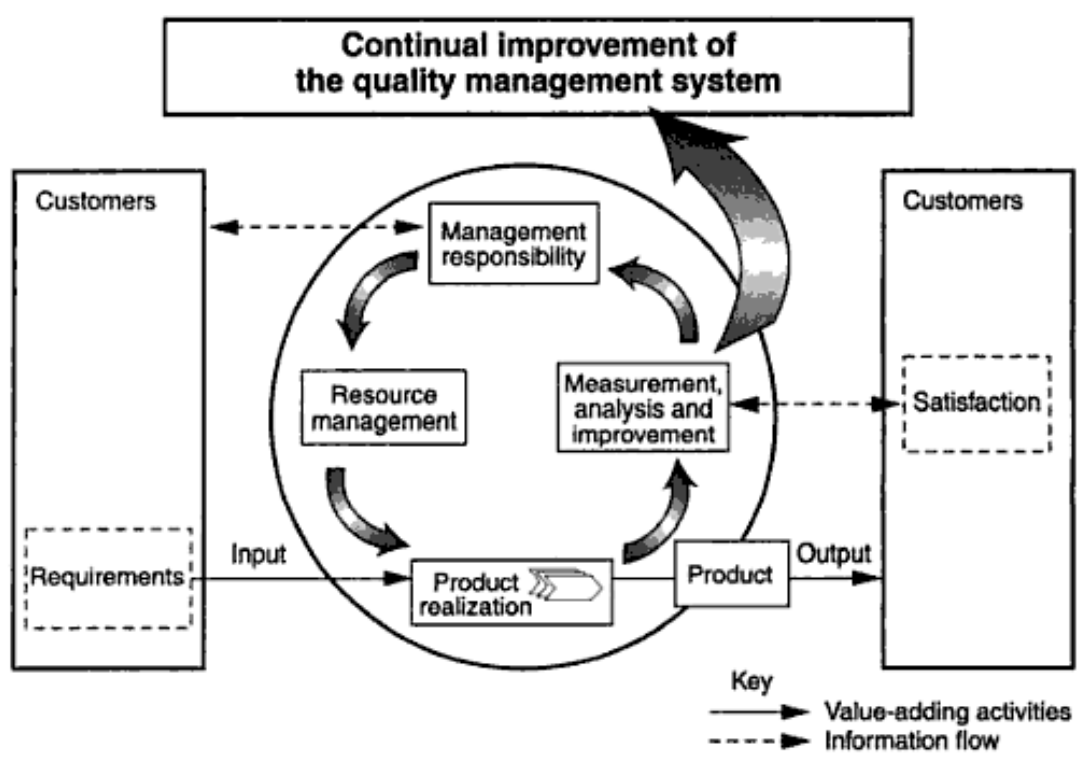

Source: Bergenhenegouwen et al. (2002) 
Figure 2. EFQM excellence model

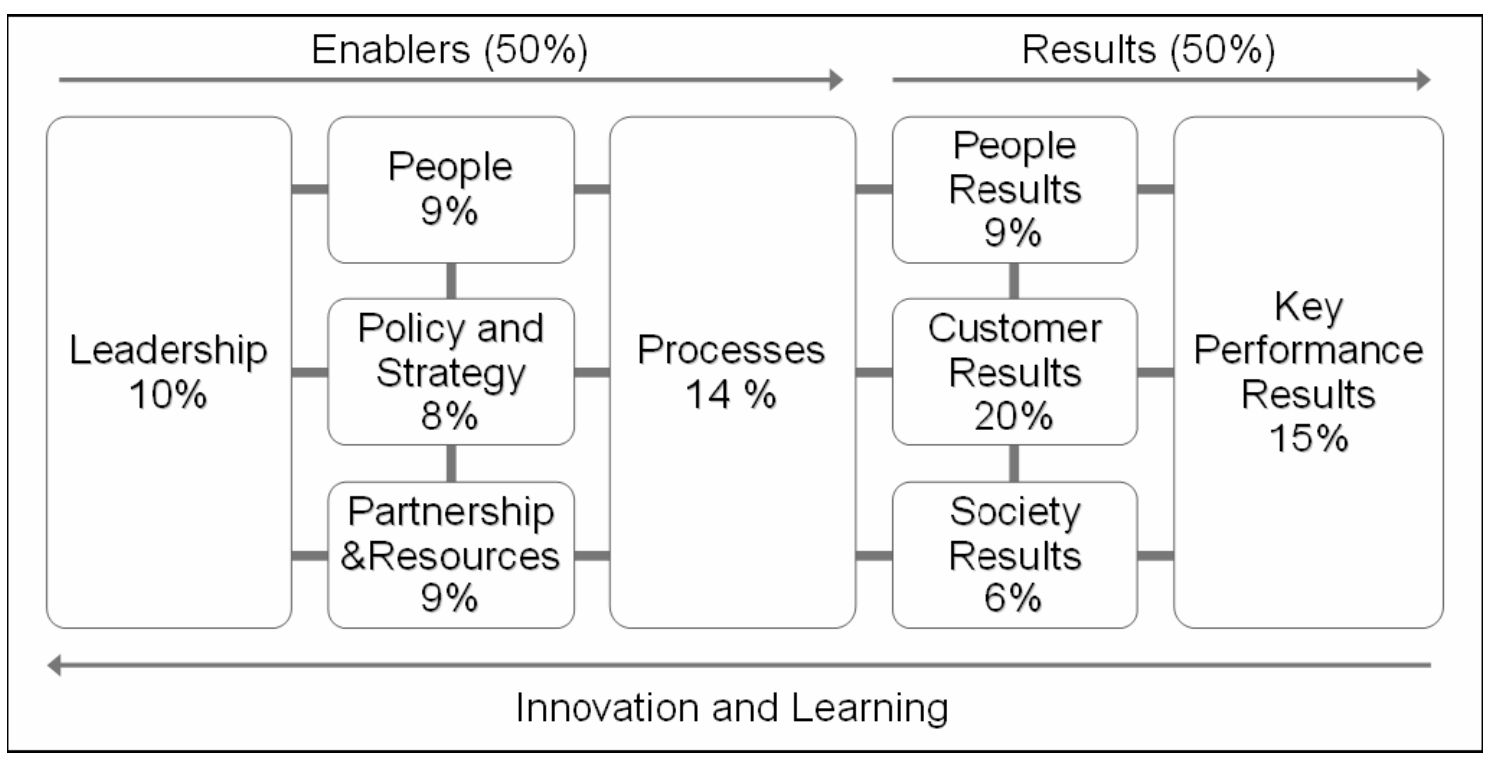


Table 1. Linkage and contribution of ISO 9000: 2000 to EFQM (Russell, 2000)

\begin{tabular}{|c|c|c|c|}
\hline \multirow{2}{*}{$\begin{array}{l}\text { Excellence } \\
\text { criterion }\end{array}$} & \multirow{2}{*}{$\begin{array}{l}\text { ISO 9001:2000 } \\
\text { contribution }\end{array}$} & \multicolumn{2}{|r|}{ Linkages } \\
\hline & & $\begin{array}{l}\text { Sub criteria } \\
\text { excellence }\end{array}$ & $\begin{array}{l}\text { ISO 9000:2000 } \\
\text { elements }\end{array}$ \\
\hline \multirow{4}{*}{ Leadership } & Low/medium & $1 \mathrm{a}$ & $5.1,5.3$ \\
\hline & & $1 b$ & 5.3, 5.4, 5.5, 5.6 \\
\hline & & 1c & 5.2 \\
\hline & & $1 d$ & $5.1,5.3$ \\
\hline \multirow[t]{5}{*}{ Policy and strategy } & Medium & $2 \mathrm{a}$ & $5.2,8.2 .1$ \\
\hline & & $2 b$ & $5.6,8.2,8.4$ \\
\hline & & 2c & 5.3 \\
\hline & & $2 \mathrm{~d}$ & 5.4 .2 \\
\hline & & $2 \mathrm{e}$ & 5.3, 5.4.1, 5.5.4 \\
\hline \multirow[t]{5}{*}{ People } & Low & За & \\
\hline & & $3 b$ & 6.2 \\
\hline & & 3c & 5.5.2, 6.2 \\
\hline & & 3d & 5.1 \\
\hline & & Зe & 6.4 \\
\hline \multirow{5}{*}{$\begin{array}{l}\text { Partnerships and } \\
\text { resources }\end{array}$} & Low/Medium & $4 a$ & \\
\hline & & $4 \mathrm{~b}$ & \\
\hline & & $4 c$ & $6.1,6.3,6.4,7.5 .1$ \\
\hline & & $4 d$ & \\
\hline & & $4 \mathrm{e}$ & 5.5.6, 5.5.7, 7.2.2, 7.3.3 \\
\hline \multirow[t]{5}{*}{ Processes } & High & $5 a$ & Covered by 4.1 \& 4.2 \\
\hline & & $5 b$ & 5.6, 7.3.7, 8.2.3, 8.4, 8.5 \\
\hline & & $5 c$ & $7.2,7.3$ \\
\hline & & $5 d$ & Addressed throughout 7 \\
\hline & & $5 e$ & $\begin{array}{c}\text { 5.2, } 7.2,8.2 .1,8.4,8.5 .2 \\
8.5 .3\end{array}$ \\
\hline \multirow[t]{2}{*}{ Customer results } & Medium & $6 a$ & $5.6,7.2 .3,8.2,8.4$ \\
\hline & & $6 b$ & 8.2.3, 8.4 \\
\hline \multirow[t]{2}{*}{ People results } & Low & $7 a$ & \\
\hline & & $7 \mathrm{~b}$ & $5.3,6.2 .2$ \\
\hline \multirow[t]{2}{*}{ Society results } & None & $8 a$ & \\
\hline & & $8 b$ & \\
\hline \multirow{2}{*}{$\begin{array}{l}\text { Key performance } \\
\text { results }\end{array}$} & Low & $9 a$ & \\
\hline & & $9 b$ & 5.6, 7.4.1, 8.2.3, 8.2.4 \\
\hline
\end{tabular}


Table 2. Descriptive statistics $(\mathbf{N}=\mathbf{6 6 5})$

\begin{tabular}{|c|c|c|c|c|c|c|}
\hline & $\begin{array}{l}\text { Total } \\
\text { sample }\end{array}$ & & $\begin{array}{l}\text { ISO } \\
9000\end{array}$ & $\begin{array}{l}\text { No ISO } \\
9000\end{array}$ & EFQM & $\begin{array}{l}\text { No } \\
\text { EFQM }\end{array}$ \\
\hline & Mean & $\begin{array}{l}\text { St. } \\
\text { dev. }\end{array}$ & Mean & Mean & Mean & Mean \\
\hline $\begin{array}{l}\text { Improvement groups } \\
\text { (\%) }\end{array}$ & 15.803 & 25.361 & 18.334 & 12.802 & 26.800 & 15.009 \\
\hline $\begin{array}{l}\text { Ordinary autonomous } \\
\text { teams (\%) }\end{array}$ & 20.268 & 32.295 & 19.653 & 20.931 & 23.533 & 19.942 \\
\hline $\begin{array}{l}\text { New projects } \\
\text { autonomous teams (\%) }\end{array}$ & 7.341 & 17.447 & 7.188 & 7.523 & 13.555 & 6.799 \\
\hline $\begin{array}{l}\text { Suggestion system (1- } \\
0)\end{array}$ & 0.645 & 0.478 & 0.726 & 0.542 & 0.883 & 0.624 \\
\hline $\begin{array}{l}\text { Informative meetings } \\
(1-0)\end{array}$ & 0.723 & 0.447 & 0.769 & 0.666 & 0.933 & 0.708 \\
\hline 20-49 employees (1-0) & 0.338 & 0.473 & 0.234 & 0.470 & 0.244 & 0.348 \\
\hline 50-99 employees (1-0) & 0.332 & 0.471 & 0.368 & 0.294 & 0.244 & 0.338 \\
\hline $\begin{array}{l}\text { 100-249 employees (1- } \\
0)\end{array}$ & 0.246 & 0.431 & 0.279 & 0.203 & 0.311 & 0.241 \\
\hline Multinational (1-0) & 0.147 & 0.354 & 0.220 & 0.054 & 0.177 & 0.146 \\
\hline Construction (1-0) & 0.106 & 0.309 & 0.109 & 0.105 & 0.022 & 0.114 \\
\hline Manufacturing (1-0) & 0.436 & 0.496 & 0.576 & 0.254 & 0.444 & 0.432 \\
\hline $\begin{array}{l}\text { Collective agreement } \\
(1-0)\end{array}$ & 0.481 & 0.500 & 0.552 & 0.402 & 0.644 & 0.469 \\
\hline ISO (1-0) & 0.566 & 0.495 & 1 & 0 & 0.777 & 0.551 \\
\hline EFQM (1-0) & 0.067 & 0.251 & 0.092 & 0.034 & 1 & 0 \\
\hline
\end{tabular}


Table 3. Correlation matrix $(\mathrm{N}=665)$

\begin{tabular}{|c|c|c|c|c|c|c|c|c|c|c|c|c|c|}
\hline & 1 & 2 & 3 & 4 & 5 & 6 & 7 & 8 & 9 & 10 & 11 & 12 & 13 \\
\hline 1. Improvement groups & & & & & & & & & & & & & \\
\hline $\begin{array}{l}\text { 2. Ordinary autonomous } \\
\text { teams }\end{array}$ & $0.238 * * *$ & & & & & & & & & & & & \\
\hline $\begin{array}{l}\text { 3. New projects } \\
\text { autonomous teams }\end{array}$ & $0.393 * * *$ & $0.462 * * *$ & & & & & & & & & & & \\
\hline 4. Suggestion system & $0.242 * * *$ & $0.098 * *$ & $0.167 * * *$ & & & & & & & & & & \\
\hline 5. Informative meetings & $0.228 * * *$ & $0.090 * *$ & $0.172^{* * *}$ & $0.331^{* * *}$ & & & & & & & & & \\
\hline 6. 20-49 employees & 0.046 & 0.039 & 0.062 & $-0.077^{*}$ & $-\overline{0.110 * * *}$ & & & & & & & & \\
\hline 7. 50-99 employees & 0.047 & 0.019 & 0.001 & 0.020 & -0.004 & $\overline{-}-502 * * *$ & & & & & & & \\
\hline 8. 100-249 employees & -0.063 & -0.031 & -0.037 & 0.021 & 0.061 & $\overline{-}-407 * * *$ & $\begin{array}{l}- \\
0.405^{* * *}\end{array}$ & & & & & & \\
\hline 9. Multinational & 0.027 & 0.004 & -0.024 & $0.093^{* *}$ & $0.159^{* * *}$ & $\overline{-}-222 * * *$ & $0.085^{* *}$ & $0.158^{* * *}$ & & & & & \\
\hline 10. Construction & $-0.060^{*}$ & $0.063^{*}$ & -0.026 & $-\overline{0.155^{* * *}}$ & $\overline{0}-185^{* * *}$ & 0.036 & 0.058 & -0.049 & $\overline{0}-143 * * *$ & & & & \\
\hline 11. Manufacturing & $-0.060^{*}$ & $-0.096 * *$ & $-0.063 *$ & $0.076^{* *}$ & $0.135^{* * *}$ & $\overline{-}-131^{* * *}$ & $-0.011^{* *}$ & $0.078^{*}$ & $0.282^{* * *}$ & $\overline{0.302 * * *}$ & & & \\
\hline 12. Collective agreement & -0.040 & 0.008 & 0.032 & $0.132^{* * *}$ & $0.158^{* * *}$ & $\begin{array}{l}- \\
0.190 * * *\end{array}$ & -0.058 & $0.129 * * *$ & $0.293^{* * *}$ & $-\overline{0.214 * * *}$ & $0.162^{* * *}$ & & \\
\hline 13. ISO & $0.096^{* * *}$ & -0.008 & -0.015 & $0.177^{* * *}$ & $0.121^{* * *}$ & $\begin{array}{l}- \\
0.249 * * *\end{array}$ & $0.072 *$ & $0.095^{* *}$ & $0.224 *$ & 0.012 & $0.315^{*}$ & $0.144^{* *}$ & \\
\hline 14. EFQM & $0.121^{*}$ & 0.023 & $0.096 * * *$ & $0.131 * *$ & $0.148 *$ & $-0.070 *$ & -0.043 & 0.047 & 0.028 & $-0.071^{*}$ & 0.003 & $0.089 * *$ & $0.106^{* * *}$ \\
\hline
\end{tabular}


Table 4. Tobit models for improvement groups, ordinary autonomous teams and new project autonomous teams

\begin{tabular}{|c|c|c|c|}
\hline & $\begin{array}{l}\text { Improvement } \\
\text { groups }\end{array}$ & $\begin{array}{l}\text { Ordinary } \\
\text { autonomous teams }\end{array}$ & $\begin{array}{l}\text { New projects } \\
\text { autonomous teams }\end{array}$ \\
\hline Constant & $\begin{array}{l}-3.5221 \\
(-0.6255)\end{array}$ & $\begin{array}{l}-23.4940 * \\
(-1.9210)\end{array}$ & $\begin{array}{l}-18.8216 * * * \\
(-3.0294)\end{array}$ \\
\hline 20-49 employees & $\begin{array}{l}13.4243^{* *} \\
(2.4910)\end{array}$ & $\begin{array}{l}19.1133 * \\
(1.6535)\end{array}$ & $\begin{array}{l}6.9797 \\
(1.1964)\end{array}$ \\
\hline 50-99 employees & $\begin{array}{l}10.8357 * * \\
(2.0727)\end{array}$ & $\begin{array}{l}16.5523 \\
(1.4724)\end{array}$ & $\begin{array}{l}6.5028 \\
(1.1554)\end{array}$ \\
\hline 100-249 employees & $\begin{array}{l}5.90228 \\
(1.1355)\end{array}$ & $\begin{array}{l}9.9832 \\
(0.8946)\end{array}$ & $\begin{array}{l}4.6260 \\
(0.8285)\end{array}$ \\
\hline Multinational & $\begin{array}{l}7.41978 * \\
(1.8443)\end{array}$ & $\begin{array}{l}8.3533 \\
(0.9755)\end{array}$ & $\begin{array}{l}1.7740 \\
(0.4123)\end{array}$ \\
\hline Construction & $\begin{array}{l}-14.2442 * * * \\
(-3.0832)\end{array}$ & $\begin{array}{l}13.4493 \\
(1.4791)\end{array}$ & $\begin{array}{l}-2.6508 \\
(-0.5342)\end{array}$ \\
\hline Manufacturing & $\begin{array}{l}-7.50036^{* *} \\
(-2.5548)\end{array}$ & $\begin{array}{l}-11.5915 * \\
(-1.8745)\end{array}$ & $\begin{array}{l}-1.2674 \\
(-0.4015)\end{array}$ \\
\hline Collective agreement & $\begin{array}{l}-3.6160 \\
(-1.2860)\end{array}$ & $\begin{array}{l}7.2433 \\
(1.2368)\end{array}$ & $\begin{array}{l}5.2830 * \\
(1.7492)\end{array}$ \\
\hline ISO & $\begin{array}{l}15.3366^{* * * *} \\
(5.2835)\end{array}$ & $\begin{array}{l}4.0837 \\
(0.6797)\end{array}$ & $\begin{array}{l}3.2540 \\
(1.0458)\end{array}$ \\
\hline EFQM & $\begin{array}{l}15.0757 * * * \\
(2.9955)\end{array}$ & $\begin{array}{l}12.8277 \\
(1.2202)\end{array}$ & $\begin{array}{l}13.5478 * * * \\
(2.5737)\end{array}$ \\
\hline Sigma & $\begin{array}{l}31.6705 * * * \\
(29.3005)\end{array}$ & $\begin{array}{l}61.5806^{* * *} \\
(21.0386)\end{array}$ & $\begin{array}{l}31.0718 \\
(21.768)\end{array}$ \\
\hline Wald-test. Chi-2 & 0.00 & 0.48 & $2.61 *$ \\
\hline $\mathrm{N}$ & 665 & 665 & 665 \\
\hline
\end{tabular}

Null hypothesis for the Wald-test is ISO = EFQM

Omitted categories for size and sector dummies are higher or equal to 250 employees and services

Standard Errors in brackets.

${ }^{* * *} \mathrm{p}<1 \%, * * \mathrm{p}<5 \%, * \mathrm{p}<10 \%$. 
Table 5. Probit models for suggestion systems and meetings

\begin{tabular}{lll}
\hline & $\begin{array}{l}\text { Suggestion } \\
\text { systems }\end{array}$ & $\begin{array}{l}\text { Informative } \\
\text { meetings }\end{array}$ \\
\hline Constant & 0.0955 & $0.5306^{* *}$ \\
20-49 employees & $(0.4122)$ & $(2.0200)$ \\
& -0.0108 & -0.2790 \\
50-99 employees & $(-0.0479)$ & $(-1.0911)$ \\
& 0.0512 & -0.1605 \\
100-249 employees & $(0.2330)$ & $(-0.6379)$ \\
Multinational & -0.0147 & -0.1085 \\
& $(-0.0669)$ & $(-0.4244)$ \\
Construction & 0.1135 & $0.4472^{* *}$ \\
& $(0.6675)$ & $(2.2326)$ \\
Manufacturing & $-0.5759^{* * *}$ & $-0.4728 * *$ \\
Collective agreement & $(-3.3003)$ & $(-2.7213)$ \\
ISO & -0.0920 & 0.1249 \\
& $(-0.7830)$ & $(1.0120)$ \\
EFQM & $0.1889 * * *$ & $0.1978 * *$ \\
& $(1.7004)$ & $(1.7081)$ \\
\hline Wald-test. Chi-2 & $0.4287 * * *$ & 0.1311 \\
\% correct predictions & $(3.7979)$ & $(1.1177)$ \\
N & $0.6806^{* * *}$ & $0.8422^{* * *}$ \\
& $(2.6545)$ & $(2.7619)$ \\
\hline
\end{tabular}

Null hypothesis for the Wald-test is ISO = EFQM

Omitted categories for size and sector dummies are higher or equal to 250 employees and services

Standard Errors in brackets.

*** $\mathrm{p}<1 \%$, ** $\mathrm{p}<5 \%$, * $\mathrm{p}<10 \%$. 